\title{
ANIMAL EXPERIMENTATION
}

\author{
Expression of Transforming Growth Factor Alpha (TGF- $\alpha$ ) \\ Gene in Mouse Embryonic Development
}

\author{
TASUKU HARADA, ${ }^{1,2}$ TOMOYUKI FUIIKAWA, ${ }^{1}$ SOUICHI YOSHIDA, ${ }^{1}$ YOSHIMASA ONOHARA, ${ }^{1}$ \\ MASAHIRO TANIKAWA, ${ }^{1}$ and NAOKI TERAKAWA ${ }^{1}$
}

Submitted: November 19, 1996

Accepted: January 7, 1997

Purpose: The expression of genes for TGF- $\alpha$, epidermal growth factor (EGF), and the EGF receptor (EGFR) in mouse blastocysts was evaluated by the reverse transcription-polymerase chain reaction (RT-PCR). We evaluated the effects of $T G F-\alpha$ and $E G F$ on the development of mouse embryo prior to implantation.

Results: The results revealed the presence of transcripts of $T G F-\alpha$ and EGFR. However, EGF $m R N A$ was not observed in repeated experiments. None of these growth factors influenced the rate of development from the two-cell stage to the blastocyst stage when added to the culture medium. These effects were further examined on measuring the incorporaiion of tritiated thymidine and leucine, providing indices of the synthesis of DNA and protein, respectively. A concentration of only $0.1 \mathrm{ng} / \mathrm{ml}$ of $T G F-\alpha$, which shares a cell surface receptor with EGF, stimulated the symthesis of both DNA and protein. EGF at a concentration of $10 \mathrm{ng} / \mathrm{ml}$ stimulated the synthesis of DNA and protein by blastocysts. To explore autocrine effects of TGF- $\alpha$ on the rate of blastocoel expansion, $T G F-\alpha$ antisense oligodeoxynucleotides was used to reduce expression of the $T G F-\alpha$ gene. $T G F-\alpha$ at a concentration of $0.1 \mathrm{ng} / \mathrm{ml}$ stimulates the rate of blastocoel expansion in early cavitating mouse blastocysts. In contrast, TGF. $\alpha$ antisense oligonucleotides significantly reduced the rate of expansion.

Conclusions: Our present observations suggest that $T G F-\alpha /$ $E G F$ and the EGFR may be involved in regulating embryonic development. In particular, TGF-a may serve as an autocrine factor in the regulation of embryonic development.

\footnotetext{
1 Department of Obstetrics and Gynecology, Tottori University School of Medicine, Yonago 683, Japan.

${ }^{2}$ To whom correspondence should be addressed.
}

KEY WORDS: antisense oligodeoxynucleotides; epidermal growth facior (EGF); EGF receptor; embryo; reverse transcriptionpolymerase chain reaction; transforming growth factor alpha.

\section{INTRODUCTION}

The expression of several growth factors (GFs) and their receptors in the preimplantation embryo and the maternal reproductive tract suggests that such factors may influence the growth and differentiation of embryonic cells in an autocrine/paracrine manner $(1,2)$. The development of embryos in vitro prior to implantation was retarded in terms of the number of cells in the embryos (3), the synthesis of DNA and RNA (4), and a reduced rate of implantation following transfer to the surrogate mother (5). These findings suggest that GFs and cytokines may enhance the development of the embryo in vivo. GFs and cytokines produced by the embryo itself or by the maternal reproductive tract were shown to stimulate embryonic development in vitro $(6-8)$. Additional information is needed about the mechanism by which the GFs regulate the growth and differentiation of the embryo prior to implantation. Such information might be useful in establishing optimal culture conditions for in vitro fertilization, in which human embryos are transferred into the uterine cavity at a suboptimal stage (two to four cells), instead of the blastcyst stage.

Our objective was to evaluate the role of transforming growth factor- $\alpha$ (TGF- $\alpha$ ), epidermal growth factor (EGF), and the EGF receptor (EGFR) ligandreceptor system in the development of preimplantation embryos. The expression in the blastcysts of mRNA of TGF- $\alpha, E G F$, and the receptor for EGF/TGF- $\alpha$ was 
evaluated by the reverse transcription-polymerase chain reaction (RT-PCR). The effects of TGF- $\alpha$ on preimplantation embryos were evaluated by sensitive measure of DNA and protein synthesis. To examine further autocrine effects of TGF- $\alpha$ on the rate of blastocoel expansion, TGF- $\alpha$ antisense oligodeoxynucleotides were used.

\section{MATERIALS AND METHODS}

\section{Growth Factors and Other Reagents}

Receptor-grade natural mouse EGF was purchased from Genzyme (MA). Recombinant human TGF- $\alpha$ was purchased from Collaborative Research Inc. (MA). Anti TGF- $\alpha$ antibody was purchased from Oncogene Science, Inc. (NY). All other culture-grade regents were obtained from Wako Pure Chemical (Tokyo) or Sigma (MO).

\section{Embryo Collection and Culture}

B6C3 $F_{1}$ mice were used in all experiments. Female mice were injected with $7.5 \mathrm{IU}$ of pregnant mare serum gonadotropin (PMSG; Sankyo Zoki Co., Ltd., Tokyo) and $10 \mathrm{IU}$ of human chorionic gonadotropin (hCG; Pregnyl; N.V. Organon, Tokyo) 48 hr apart. Immediately after the hCG injection, the female mice were placed with the male. Two-cell embryos were collected from the oviducts of the mated female mice $44 \mathrm{hr}$ after hCG injection. Biggers-Whitten-Whittingham (BWW) medium was prepared as detailed previously (4). GFs were added to BWW medium containing bovine serum albumin, $1 \mathrm{mg} / \mathrm{ml}$ (BSA; Fraction V, Sigma). Cultures were maintained at $37^{\circ} \mathrm{C}$ in an atmosphere of $5 \% \mathrm{CO}_{2}$ in air.

\section{RT-PCR}

Total RNA was extracted from blastocysts (20-50 per group) by the guanidinium thiocyanate method as described by Chomczynski and Sacchi (9). The detailed procedures followed the guidelines provided by the manufacturer (Isogen; Nippon Gene Co., Tokyo). To maximize isolation of RNA, $20 \mu \mathrm{g}$ of yeast transfer RNA was added as a carrier. RNA from embryos was reverse transcribed into cDNA by use of a cDNA Cycle kit (Invitrogen, San Diego, CA). The reverse transcription of RNA to CDNA was performed with $5 \mathrm{U}$ of $A M V$ reverse transcriptase.
Amprification was carried out in $50 \mathrm{mM} \mathrm{KCl}, 10$ $\mathrm{m} M$ Tris- $\mathrm{HCl}$ ( $\mathrm{pH} \mathrm{8.8),} 1.5 \mathrm{mM} \mathrm{MgCl}{ }_{2}$, and $2 \mathrm{U}$ Taq DNA polymerase (Nipppon Gene). Each cycle consisted of $1 \mathrm{~min}$ at $94^{\circ} \mathrm{C}, 1 \mathrm{~min}$ at $55^{\circ} \mathrm{C}$, and $2 \mathrm{~min}$ at $75^{\circ} \mathrm{C}$. The specific primer pairs were derived from published sequences for mouse $\beta$-actin, EGF, TGF- $\alpha$, and EGFR cDNA sequences and were as follows: $\beta$ actin- $5^{\prime}$ primer $=5^{\prime}$ TCGTGGGCCGCTCTAGGCA $\mathrm{C}^{\prime}, 3^{\prime}$ primer $=5^{\prime}$ TGGCCTTAGGGTTCAGGGG G3' PCR amplified cDNA $=243$ bp (1); EGF-5' primer $=5^{\prime}$ CCAGTTCAGTAGAAACTGGG3', 3' primer $=5^{\prime}$ 'TGGTTTCTAATGATTTTCTCC $3^{\prime}$ PCR amplified $\mathrm{cDNA}=247$ bp (10); TGF- $\alpha-5^{\prime}$ primer $=5^{\prime}$ ACCTGCAGGTTTTTGGTGCAG3', 3' primer

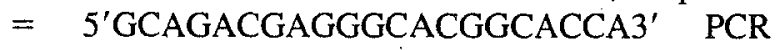
amplified cDNA = $239 \mathrm{bp}(11)$; and EGFR-5' primer $=$ 5'GGAGGAAAAGAAAGTCTGCC 3', 3' $^{\prime}$ primer $=5^{\prime}$ CCCATAGTTGGACAGGATGG $3^{\prime}$ PCR amplified $\mathrm{cDNA}=248 \mathrm{bp}(12)$.

PCR products were resolved on $2 \%$ agarose gels along with a small molecular weight DNA marker $(\phi \times 174$ digested with HaelII).

For restriction enzyme analysis, amplified PCR products were treated with phenol-chloroform and resuspended in the appropriate buffer for restriction enzymes (Nippon Gene).

\section{Thymidine and Leucine Incorporation}

To quantify the synthesis of DNA and protein, the incorporation of thymidine and leucine was measured by the methods described previously $(4,13)$. In brief, blastocysts that had been cultured in the medium supplemented with various growth factors were washed three times in BWW medium containing only BSA. Embryos were then transferred to a medium containing, ${ }^{3} \mathrm{H}$-thymidine, $50 \mu \mathrm{Ci} / \mathrm{ml}$ (sp/act, $25 \mathrm{Ci} / \mathrm{mmol}$; Amersham Japan, Tokyo), or ${ }^{3} \mathrm{H}$-leucine, $50 \mu \mathrm{Ci} / \mathrm{ml}$ (sp/act, $5 \mathrm{Ci} / \mathrm{mmol}$; Amersham Japan), and incubated for $4 \mathrm{hr}$. After being washed five times in cold PBS, three to five embryos were transferred to a $1.5-\mathrm{ml}$ microcentrifuge tube. The addition of $200 \mu \mathrm{l}$ of distilled water was followed by two cycles of freezing and thawing, then by precipitation with $20 \%$ trichloroacetic acid. The precipitate was dissolved in a tissue homogenizer (Soluene 350, Packard Japan). Liquid scintillation counting was carried out in a Beckman LS 5801. Incorporation of thymidine and leucine was calculated and is expressed as counts (dpm) per embryo. 


\section{Measurement of the Rate of Blastocoel Expansion}

Early cavitating blastocysts cultured from the twocell stage were placed in $1 \mathrm{ml}$ of the culture medium containing TGF- $\alpha$ or oligonucleotides. The rate of increase in blastocoel volume was measured essentially as described previously $(14,15)$. The volume of the cavity was determined by measuring the area of the blastocoel cavity on an Olympus inverted microscope at a 200 -fold magnification; the focal plane was adjusted to measure the maximum diameter of the cavity. The embryos were then cultured at $37^{\circ} \mathrm{C}$ in $5 \%$ $\mathrm{CO}_{2}$ in air and the size of the blastocoel cavity was measured $6 \mathrm{hr}$ later.

\section{Oligonucleotides}

The designs of oligodeoxynucleotides used in this study showing sequence position by nucleotide are given below. The oligomers were designed to overlap the initiation codon of the rat TGF- $\alpha$ mRNA (11). TGF- $\alpha$ phosphorothioate oligonucleotide was synthesized by Nippon Gene.

Initiation codon oligonucleotides:

TGF- $\alpha$ antisense, $5^{\prime}$-CGGGGACCATCTTCC3'; sense, 5'-GGAAGATGGTCCCCG-3'.

\section{Statistical Analysis}

Data are expressed as mean \pm standard error of the mean (SE). Results were evaluated by the nonparametric Mann-Whitney test, with $P<0.05$ considered statistically significant.

\section{RESULTS}

\section{Expression of TGF- $\alpha$ and the EGFR Gene in the Mouse Blastocyst}

Total RNA isolated from 20,30 , and 50 blastocysts was used in RT-PCR for $\beta$-actin expression as a control for RNA integrity. Using primers specific for $\beta$-actin, all samples gave an amplified product of the predicted size (243 bp) and approximately concentration dependent in intensity (Fig. 1A).

Results in Fig. 1B indicate that the EGFR gene is expressed in the blastocyst. After amplification by the first 30 cycles, only the PCR product for $\beta$-actin was visualized; nested PCR for another 30 cycles generated sufficient ethidium bromide fluorescence to show the predicted $248 \mathrm{bp}$ of the EGFR PCR fragment. To verify that the correct target sequence had been amplified by the PCR reaction, PCR products were digested with PstI. The 248-bp EGFR PCR fragment was digested to yield two fragments, 173 and $75 \mathrm{bp}$ in length, as predicted from the mouse $\mathrm{CDNA}$ sequence. Expression of the TGF- $\alpha$ gene was also detected by repeated amplification (Fig. 1C). The fragment was cut by $S p h \mathrm{I}$, generating two fragments with predicted lengths. In contrast, transcripts of the EGF gene were not amplified in repeated experiments.

\section{Effects of TGF- $\alpha$ on the Development of Mouse Two-Cell Embryos}

TGF- $\alpha$ and EGF were tested for potential mitogenic effects on mouse embryos. The number of blastocysts was recorded after $48 \mathrm{hr}$ of culture in the medium, with GF added at a concentration of $0.1,1$, or $10 \mathrm{ng} /$ $\mathrm{ml}$. None of the GF-supplemented media enhanced the rate of development of blastocysts compared with the control (Table I).

\section{DNA Synthesis by Mouse Blastocysts Grown in Medium Supplemented with TGF-a}

The effects of various concentration of TGF- $\alpha$ or EGF on DNA synthesis in the embryos was examined, since they share a cognate cell surface receptor. EGF, at $10 \mathrm{ng} / \mathrm{ml}$, produced a significant increase in thymidine incorporation. TGF- $\alpha$, at $0.1 \mathrm{ng} / \mathrm{ml}$, also stimulated thymidine incorporation. This concentration was 100 times lower than the concentration of EGF required (Fig. 2).

\section{Effects of TGF- $\alpha$ on the Protein Synthesis by Blastocysts}

We measured the incorporation of leucine in blastocysts grown from two cell embryos in a medium containing TGF- $\alpha$ or EGF. As in the measurement of DNA synthesis, EGF, $10 \mathrm{ng} / \mathrm{ml}$, and TGF- $\alpha, 0.05$ and 0.1 $\mathrm{ng} / \mathrm{ml}$, stimulated the incorporation of leucine (Fig. 3). These results suggest that a similar effect of EGF and TGF- $\alpha$ on embryonic cell function but that TGF- $\alpha$ may be more potent. To minimize the possibility that a contaminant present in the growth factor preparations was responsible for stimulating the protein synthesis, a neutralizing antibody directed against TGF- $\alpha$ to block specific action. The positive effects of TGF- $\alpha$ were abolished by the addition of $0.2 \mu \mathrm{g} / \mathrm{ml}$ anti TGF- $\alpha$ antibody. 

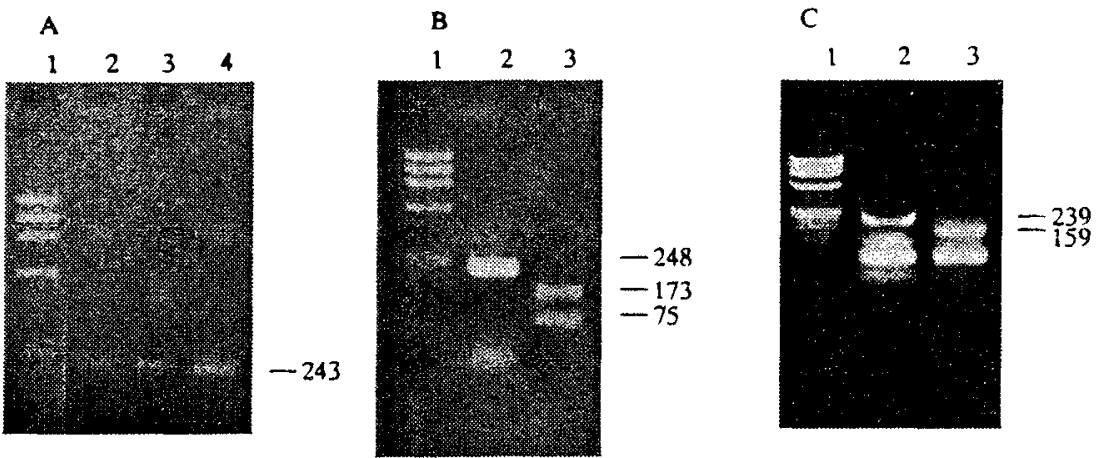

Fig. 1. Expression of mRNA for $\beta$-actin, the EGFR, and TGF- $\alpha$ by mouse blastocysts. RT-PCR was performed as described under Materials and Methods. (A) Transcripts for $\beta$-actin generated from 20,30 , and 50 blastocysts by the first 30 cycles in lanes 2,3 , and 4 , respectively. (B) Undigested (lane 2) and PstI-digested (lane 3) transcripts for EGFR were electrophoresed through agarose gel. (C) Undigested (lane 2) and Sphl-digested transcripts for TGF- $\alpha$ are shown. HaelIIdigested $\phi \times 174$ DNA size markers were used in the left lane.

\section{Effects of TGF- $\alpha$ Antisense Oligonucleotides on Blastocoel Expansion}

Treatment of early cavitating blastocysts with 0.1 $\mathrm{ng} / \mathrm{ml}$ TGF- $\alpha$ stimulated the rate of blastocoel expansion (Fig. 4). The preimplantation embryos tolerated the oligonucleotides well, and toxicity with control sense oligonucleotides was seen only above $50 \mu M$. Exposure to $10 \mu M$ antisense oligonucleotides resulted in a significant decrease in the rate of blastocoel expansion. Sense oligonucleotides at the same concentration had no detectable effect on the rate of expansion (Fig. 4).

\section{DISCUSSION}

The results of RT-PCR showed that transcripts of the TGF- $\alpha$ and EGFR genes, but not of the EGF gene,

Table I. Development of Blastocysts Following Culture of TwoCell Embryos in a Medium Containing TGF- $\alpha$ or EGF

\begin{tabular}{lcc}
\hline $\begin{array}{l}\text { Treatment } \\
(\mathrm{ng} / \mathrm{ml})\end{array}$ & $\begin{array}{c}\text { No. of 2-cell embryos } \\
\text { cultured }\end{array}$ & No. of blastocysts $(\%)$ \\
\hline Control & 335 & $299(89)$ \\
TFG- $\alpha$ & & \\
0.1 & 67 & $60(90)$ \\
1 & 76 & $66(87)$ \\
10 & 84 & $78(93)$ \\
EGF & & \\
0.1 & 65 & $55(88)$ \\
1 & 111 & $96(86)$ \\
10 & 131 & $116(89)$ \\
\hline
\end{tabular}

were expressed by blastocysts. We stimulated mouse preimplantation embryos to increase the synthesis of DNA and protein by exposing them to TGF- $\alpha$ and EGF. TGF- $\alpha$ and EGF probably possess similar biological activities, because they bind to the same cell surface tyrosine kinase receptor (16). However, the results of this study suggested that TGF- $\alpha$ may be more potent than EGF. Autocrine effects of TGF- $\alpha$ on the rate of blastocoel expansion were examined using TGF$\alpha$ antisense oligodeoxynucleotides. TGF- $\alpha$ antisense oligodeoxynucleotides, which were used to reduce the expression of specific gene, significantly reduced the rate of expansion. The results suggest that TGF- $\alpha$ may be an important autocrine factor in the regulation of embryonic development.

In RT-PCR experiments, expression of $\beta$-actin mRNA was detected after the standard 30 cycles of PCR, while mRNA of TGF- $\alpha$ and EGFR was visualized by ethidium bromide staining only after an additional 30 cycles of amplification. These results were reproducible. TGF- $\alpha$ transcripts have been detected in the unfertilized mouse oocyte and are rapidly destroyed at the two-cell stage, but are later resynthesized by the preimplantation conceptus $(1,17)$. In contrast, expression of the EGF gene is not observed until after implantation and the beginning of organogenesis (18-20). EGFR mRNA and protein have been identified throughout the development of the mouse embryo from the unfertilized oocyte (21) to the postimplantation embryo $(22,23)$. Our observations are consistent with these reports. 


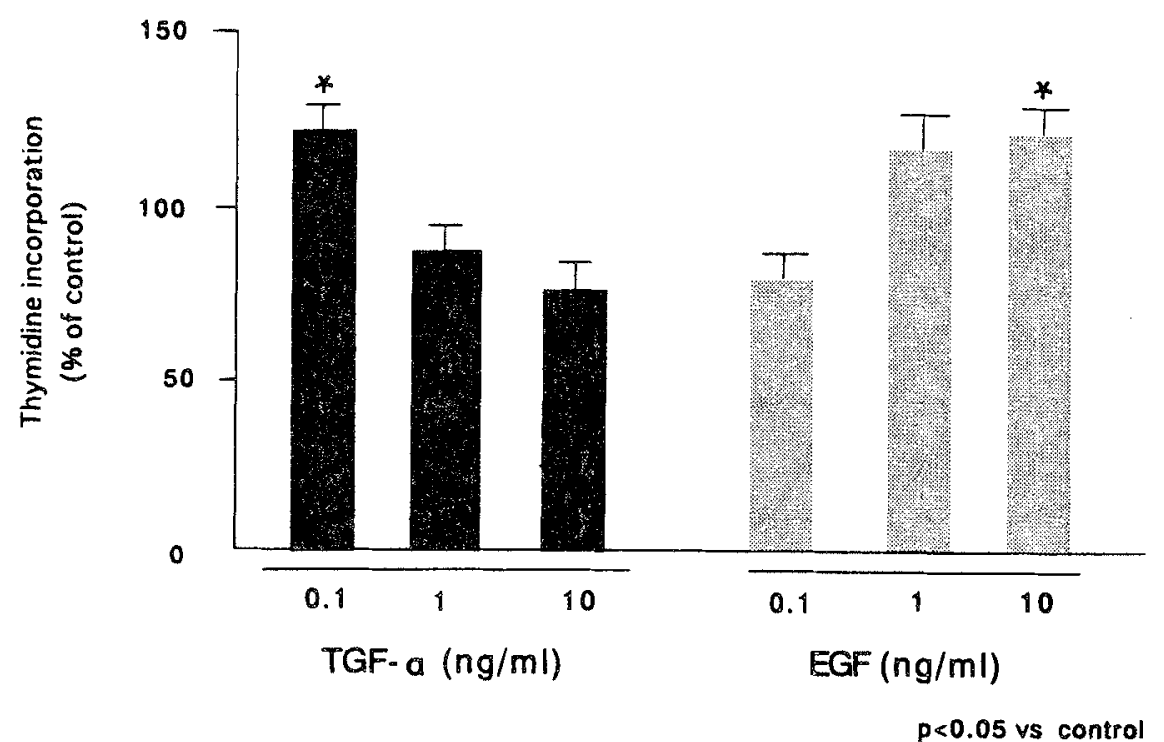

Fig. 2. Thymidine incorporation by blastocysts cultured in the medium containing various concentrations of TGF- $\alpha$ or EGF. Each sample consisted of three to five embryos. The asterisk indicates a significant difference compared to the control $(P<0.05)$. The data are expressed as mean $\pm \mathrm{SE}$.

The expression of EGF, TGF- $\alpha$, and the EGFR has been reported in fallopian tubes of humans $(8,24,25)$. It has been shown that the expression of EGF and TGF- $\alpha$ mRNA in fallopian tissue is cycle dependent and influenced by ovarian steroids $(8,25)$. Expression of both GFs has also been demonstrated in mouse uterine epithelial cells $(26,27)$. The results suggest that EGF and TGF- $\alpha$ are important autocrine/paracrine fac- tors, being involved in a variety of tubal or uterine functions.

Several authors explored the effects of GFs on preimplantation embryo development by measuring the rate of in vitro development, the number of cells per blastocyst, or the number of implantations after transfer $(28-30)$, but no stimulatory effects were detected. Our results for effects on the rate of blastocyst forma-

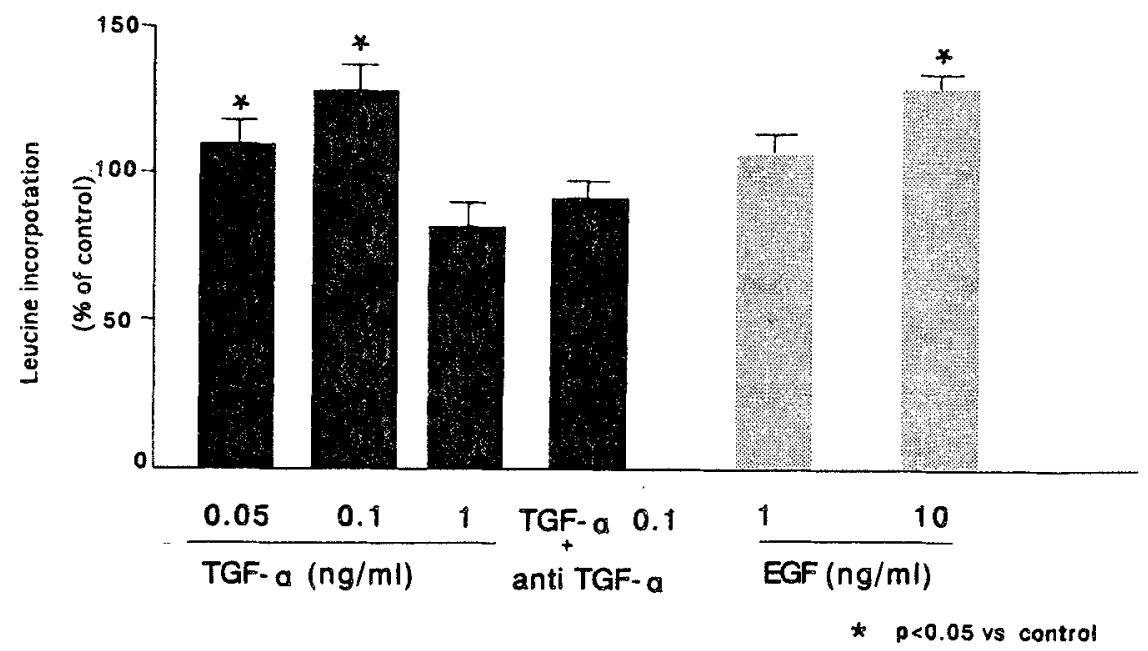

Fig. 3. Leucine incorporation by blastocysts cultured in a medium containing various concentrations of TGF- $\alpha$ or EGF. Anti TGF- $\alpha$ antibody was used for neutralizing the effects of TGF$\alpha$. Each sample consisted of three embryos. The asterisk indicates a significant difference from the control $(P<0.05)$. The data are expressed as mean $\pm \mathrm{SE}$. 


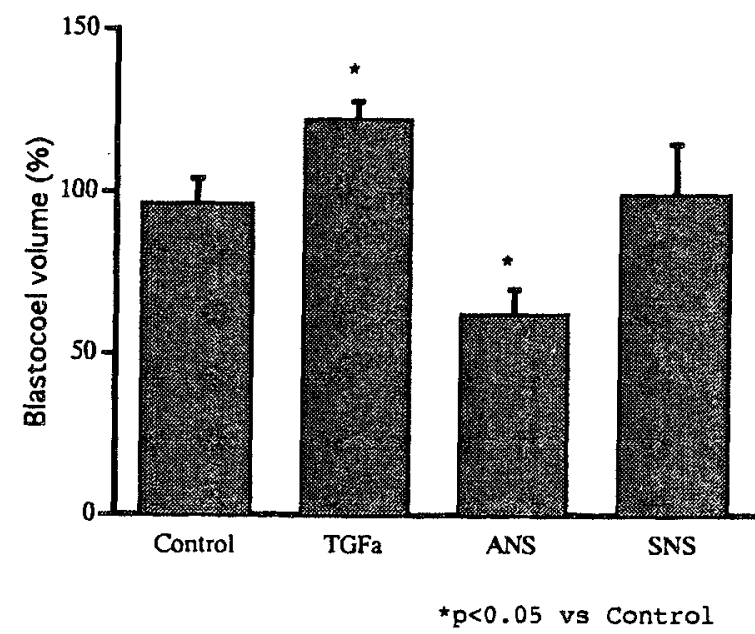

Fig. 4. Effect of TGF- $\alpha$ antisense oligonucleotide on blastocoel expansion. Early cavitating blastocysts were treated with $0.1 \mathrm{ng} /$ $\mathrm{ml}$ TGF- $\alpha$ or antisense (ANS) or sense (SNS) oligonucleotide at a concentration of $10 \mu \mathrm{M}$.

tion from two-cell stage embryos in GF-supplemented media were also not significant. The effects of TGF- $\alpha$ or EGF have been manifested as stimulation of protein synthesis (29), an increased rate of development of singly cultured embryos (6), and stimulation of the rate of blastocoel expansion (15). We used measurements of the incorporation of tritiated thymidine and leucine as indices of the synthesis of DNA and protein, respectively, because they can detect subtle differences in embryonic cell function $(4,31)$. Our results showed that stimulation of the synthesis of DNA and of protein by TGF- $\alpha$ was detected at a lower concentrations $(0.1$ $\mathrm{ng} / \mathrm{ml})$ than was stimulation by EGF $(10 \mathrm{ng} / \mathrm{ml})$. Brucker et al. (32) reported that concentrations of TGF- $\alpha$ as low as $0.1 \mathrm{ng} / \mathrm{ml}$, a level consistent with our observations, stimulated the breakdown of the enclosed mouse oocyte germinal vesicle. Although TGF- $\alpha$ and EGF exert similar effects in many systems, TGF- $\alpha$ appears to be more potent than EGF in terms of $\mathrm{Ca}^{2+}$ release $(33,34)$, prostaglandin synthesis in vascular endothelial cells (35), and an increase in arterial blood flow (36) and in angiogenesis (37). However, differences in the binding of EGF and TGF- $\alpha$ to EGFR may alter the biological activities (38).

TGF- $\alpha$ is a 50 -amino acid polypeptide derived from a 160-amino acid transmembrane precursor by specific proteolytic cleavage (39). Cultured preimplantation mouse embryos produced TGF-like bioactivity that promotes anchorage-independent growth (40). TGF- $\alpha$ activity is also produced by human embryos in culture at the time of transformation of morula to blastocyst (41). In light of these studies and present observations suggesting that $\mathrm{TGF}-\alpha$ may have a role as an autocrine factor, we used TGF- $\alpha$ antisense oligonucleotide to reduce expression of the endogenous $T G F-\alpha$ gene. Antisense oligonucleotides have been used to reduce the expression and function of intracellulary expressed genes such as c-myc (42) and growth factors (43), and thus they are a proven method for decreasing gene expression in preimplantation mouse embryos (44). To examine the autocrine effects of TGF- $\alpha$, we used TGF$\alpha$ antisense oligonucleotide to supress TGF- $\alpha$-mediated stimulation of the rate of blastocoel expansion. It has been reported that picomolar concentrations of exogenous EGF or TGF- $\alpha$ increase the rate of fluid uptake and of blastocoel expansion in the early cavitating blastocysts of preimplantation mouse embryos (15). In this study, TGF- $\alpha$ antisense oligonucleotides significantly reduced the rate of blastocoel expansion. These results suggest that TGF- $\alpha$ may be an important autocrine growth factor for preimplantation embryos.

In conclusion, EGF and TGF- $\alpha$ may be important in regulating the development of the mouse prior to implantation, acting via their common receptor. The stimulatory effects of TGF- $\alpha$ on embryonic cell function and expression of the TGF- $\alpha$ gene by mouse blastocysts lead to the hypothesis that $\mathrm{TGF}_{-} \alpha$ is an autocrine growth factor that may work in the local environment of the embryos. TGF- $\alpha$ antisense experiments suggest that TGF- $\alpha$ may be required for development and differentiation of the preimplantation embryo.

\section{ACKNOWLEDGMENTS}

This work was supported by grants-in-aid from the Japanese Ministry of Education (04771199, 06671654).

\section{REFERENCES}

1. Rappolee DA, Brenner CA, Schultz R, Mark D, Werb Z: Developmental expression of PDGF, TGF- $\alpha$, and TGF- $\beta$ genes in preimplantation mouse embryos. Science 1988;241:1823-1825

2. Telford NA, Hogan A, Franz CR, Schultz GA: Expression of genes for insulin and insulin-like growth factors and receptors in early postimplantation mouse embryos and embryonal carcinoma cells. Mol Reprod Dev 1990;27:81-92

3. Streffer C, van Beuningen D, Molls M, Zamboglou N, Schulz $S$ : Kinetics of cell proliferation in the preimplanted mouse embryo in vivo and in vitro. Cell Tissue Kinet 1980;13:135-143

4. Harada T, Tanikawa M, Iwabe T, Onohara Y, Mio Y, Terakawa $\mathrm{N}$ : Measurement of uptake and incorporation of nucleic acid precursors by preimplantation mouse embryos after develop- 
ment in vivo and in vitro. J Assist Reprod Genet 1992;9: $551-556$

5. Massip A, Van der Zwalman P, Puissant F, Camus M, Leroy R: Effects of in-vitro fertilization, culture, freezing and transfer on the ability of mouse embryos in vitro. J Reprod Fertil 1984;71:199-204

6. Paria BC, Dey SK: Preimplantation embryo development in vitro: Cooperative interactions among embryos and role of growth factors. Proc Natl Acad Sci USA 1990;87:4756-4760

7. Harvey MB, Kaye PL: Insulin stimulates protein synthesis in compacted mouse embryos. Endocrinology 1989;122:11821184

8. Morishige K-I, Kurachi H, Amemiya K, Adachi H, Sakoyama Y, Miyake A, Tanizawa O: Menstrual stage-specific expression of epidermal growth factor and transforming growth factor- $\alpha$ in human oviduct epithelium and their role in early embryogenesis. Endocrinology 1993;133:199-207

9. Chomczynsky P, Sacchi N: Single step method of RNA isolation by acid guanidinium thiocyanate-phenol-chloroform extraction. Anal Biochem 1987;162:156-159

10. Gray A. Dull T, Ullich A: Nucleotide sequence of epidermal growth factor cDNA predicts a 128,000 molecular weight protein precursor. Nature 1983;303:722-726

11. Blasband AJ, Rogers KT, Chen X, Azizkhan JC, Lee DC: Characterization of the rat transforming growth factor alpha gene and identification of promoter sequences. Mol Cell Biol 1990;10:2111-2121

12. Avivi A, Lax I, Ullrich A, Schlessinger J, Givol D, Morse B: Comparison of EGF receptor sequences as a guide to study of the ligand binding site. Oncogene 1991:6:673-676

13. Tanikawa M: Effects of human serum supplementation on fertilization and development of mouse embryos. Asia-Ocean J Obstet Gynaecol 1994;20:209-215

14. Manejwala FM, Gragoe EJ, Schultz RA: Blastocoel expansion in the preimplantation mouse embryo: Role of extracellular sodium and chloride and possible apical routes of the entry. Dev Biol 1989;133:210-220

15. Dardik A, Schultz RM: Blastocoel expansion in the preimplantation mouse embryo: Stimulatory effect of TGF- $\alpha$ and EGF. Development 1991;113:919-930

16. Burgess AW: Epidermal growth factor and transforming growth factor $\alpha$. Br Med Bull 1989;45:401-424

17. Werb Z: Expression of EGF and genes in early mammalian development. Mol Reprod Dev 1990;27:10-15

18. Kronmiller JE, Upholt WB, Kollar EJ: EGF antisense oligodeoxynucleotides block murine odontogenesis in vitro. Dev Biol 1991;147:485-488

19. Snead ML. Luo W, Oliver P, Nakamura M, Don-Wheeler G, Bessem C, Bell GI, Rall LB, Slavkin HC: Localization of epidermal growth factor in tooth and lung during embryonic mouse development. Dev Biol 1989;134:420-429

20. Warnburton D, Seth R, Shum L. Horcher PG, Hall FL, Werb Z, Slavkin HC: Epigenetic role of epidermal growth factor expression and signaling in embryonic mouse lung morphogenesis. Dev Biol 1992;149:123-133

21. Wiley LM, Wu JX, Harari I, Adamson ED: Epidermal growth factor receptor and protein increase after the four-cell stage in murine development. Dev Biol 1992;149:247-260

22. Adamson ED, Deller MJ, Warshaw JB: Functional EGF receptors are present on mouse embryo tissues. Nature 1981;291: 656-659

23. Adamson ED: EGF receptor activities in marnmalian development. Mol Reprod Dev 1990;27:16-22
24. Lei ZM Rao ChV: Expression of epidermal growth factor (EGF) receptor and its ligands, EGF and transforming growth factor $\alpha$ in human fallopian tubes. Endocrinology 1992;131:947-957

25. Chegini N, Zhao $\mathrm{Y}$, Mclean FW: Expression of messenger ribonucleic acid and presence of immunoreactive proteins for epidermal growth factor (EGF), transforming growth factor alpha $(\mathrm{TGF} \alpha)$ and EGF/TGF $\alpha$ receptors and ${ }^{125}$ I-EGF binding sites in human fallopian tube. Biol Reprod 1994;50:10491058

26. Huet-Hudson YM, Chakraborty C, De SK, Suzuki Y, Andrews GK. Dey SK: Estrogen regulates synthesis of EGF in mouse uterine epitherial cells. Mol Endocrinol 1990;4:510-523

27. Tamada H, Das SK, Andrews GK, Dey SK: Cell-type-specific expression of transforming growth factor- $\alpha$ in the mouse uterus during the peri-implantation period. Biol Reprod 1991; $45: 365-372$

28. Caro CM, Trounson A, Kirby C: Effect of growth factors in culture medium on the rate of mouse embryo development and viability in vitro. J Vitro Fert Embryo Transfer $1987 ; 4: 265-268$

29. Wood SA, Kaye PL: Effects of epidermal growth factor on preimplantation mouse embryos. J Reprod Fertil 1989;85: 575-582

30. Colver RM, Howe AM, McDonough PG, Boldt J: Influence of growth factors in defined culture medium on in vitro development of mouse embryos. Fertil Steril 1991;55:194-199

31. Jung T, Fischer B, Beier HM: Quantitative aspects of protein synthesis in non-cultured and cultured rabbit blastocysts. Hum Reprod 1987;2:23-27

32. Brucker C, Alexander NJ, Hodgen GD, Sandow BA: Transforming growth factor-alpha augments meiotic maturation of cumulus cell-enclosed mouse oocytes. Mol Reprod Dev 1991;28:94-98

33. Stem PH, Krieger NS, Nissenson RA, Williams RD, Winkle ME, Derynck R, Strewler GJ: Human transforming growth factor- $\alpha$ stimulates bone resorption in vitro. J Clin Invest 1985;76:2016-2019

34. Ibbotson KJ, Harod J, Gowen M, D'Sonza S, Winkler ME, Derynck R, Mundy GR: Human recombinant transforming growth factor alpha stimulates bone resorption and inhibits formation in vitro. Proc Natl Acad Sci USA 1986;83:22282232

35. Ristimaki A: Transforming growth factor- $\alpha$ stimulates prostacyclin production by cellular human vascular endothelial cell more potently than epidermal growth factor. Biochem Biophys Res Commun 1989;160:1100-1105

36. Gan BS, Hollenberg MD, MacCannell KL, Lederis K, Winkler ME, Derynck R: Distinct vascular actions of epidermal growth factor-urogastrone and transforming growth factor- $\alpha$. J Pharmacol Exp Ther 1987;242:331-337

37. Schreiber $A B$, Winkler ME, Derynck R: Transforming growth factor- $\alpha$ : A more potent angiogenic mediator than epidermal growth factor. Science 1986;232:1250-1253

38. Winkler ME, O'Connor L, Winget M, Fendly B: Epidermal growth factor and transforming growth factor $\alpha$ bind differently to the epidermal growth factor receptor. Biochemistry 1989;28:6373-6378

39. Derynck R, Roberts AB, Winkler ME, Chen EY, Goeddel DV: Human transforming growth factor- $\alpha$ : Precursor structure and expression in E. coli. Cell 1984;38:287-297

40. Rizzino A: Early mouse embryos produce and release factors with transforming growth factor activity. In Vitro Cell Dev Biol 1985;21:531-536 
41. Hemmings R, Langlais J, Falcone T, Granger L, Miron P, Guyda $\mathrm{H}$ : Human embryos produce transforming growth factor $\alpha$ activity and insulin-like growth factors II. Fertil Steril 1992;58:101-104

42. Holt JT, Render RL, Nienhuis AW: An oligomer complementary to c-myc mRNA inhibits proliferation of $\mathrm{HL}-60$ promyelotic cells and induces differentiation. Mol Cell Biol 1988;8:963-973
43. Becker D, Meier CB, Herlyn M: Proliferation of human malignant melanomas is inhibited by antisense oligodeoxynucleotides targeted against basic fibloblast growth factor. EMBO J 1989;8:3685-3691

44. Bevilacqua A, Erickson RP, Hieber V: Antisense RNA inhibits endogenous gene expression in mouse preimplantation embryos: Lack of double-stranded RNA "melting" activity. Proc Natl Acad Sci USA 1988;85:831-835 